\title{
Entre o saneamento e o meio ambiente: engenharia e política no final do Império e na Primeira República
}

\author{
Sanitation versus environment: engineering and politics at \\ the end of the Empire and under the First Republic
}

\author{
Pedro Eduardo Mesquita de Monteiro Marinho \\ Pesquisador do Museu de Astronomia e Ciências Afins. \\ pedro@mast.br
}

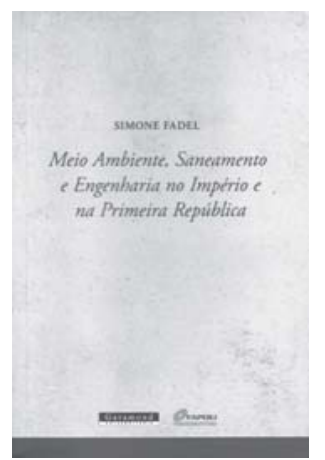

FADEL, Simone. Meio ambiente, saneamento $e$ engenharia no Império e na Primeira República. Rio de Janeiro: Garamond Universitária, 2009. 256 p.
$\mathrm{F}$ ruto de pesquisa realizada por Simone Fadel no Programa de Pós-graduação em História Social da Universidade de São Paulo (USP), o livro Meio ambiente, saneamento e engenharia no Império e na Primeira República analisa a questão da urbanização e do saneamento, com destaque para o papel dos engenheiros. Para tanto, a autora investiga a Comissão Federal de Saneamento da Baixada Fluminense, instituída em 1910 e extinta em 1916, que teve como atribuição propor obras para o saneamento de rios, de modo a restituir à agricultura e à pecuária um trecho de cerca de quatro mil quilômetros nas imediações da capital do Rio de Janeiro. Com esse objetivo, a Comissão realizou um levantamento completo da bacia hidrográfica da região, o que até então inexistia.

Em termos gerais, a mesma temática foi trabalhada por outros autores sob diferentes perspectivas. No entanto, Fadel o faz por um prisma inovador, particularmente por focar sua análise num espaço rural (o da Baixada Fluminense) e não num espaço urbano, como é

o caso da cidade do Rio de Janeiro, objeto exaustivamente explorado por diversos trabalhos historiográficos, sobretudo por aqueles que abordam a chamada Reforma Pereira Passos.

O trabalho de Fadel também é original no que diz respeito à pesquisa biográfica sobre o engenheiro Fábio Hostílio de Moraes Rego, responsável pela Comissão de Saneamento. Ressalte-se que o caráter biográfico, em certa medida, de sua pesquisa prima pela escolha desse personagem, que, embora tenha importância histórica, não foi tão estudado como André Rebouças, Paulo de Frontin, Pereira Passos, Saturnino Britto, entre outras grandes figuras.

Ao mesmo tempo, a abordagem de Simone Fadel não peca no que Bourdieu (1996) denomina ilusão biográfica, ou seja, o estabelecimento de uma relação direta entre todos os dados biográficos de uma personagem com o que é considerado o mais importante pela biografia em questão, como se aqueles, teleologicamente, fossem uma antecipação deste último. Sobre esse aspecto, é importante observar como Fadel relaciona sujeito e estrutura na história, sem que aquele seja tratado como independente desta e sem que a estrutura atue 
como um verdadeiro sujeito da história. Desse modo, a ação do sujeito deixa de ser um mero reflexo dos interesses, por exemplo, do capital mercantil ou de qualquer outro elemento causal.

Em relação aos interesses em jogo, Fadel mostra como os engenheiros do início do século XX, e particularmente Fábio Hostílio de Moraes Rego, procuraram colocar em prática uma agenda política de modernização para o país. O trabalho, portanto, combina a análise de detalhes factuais com a totalidade, realizando uma adequada articulação entre macro e micro-história, visto que, na realidade, é impossível compreender uma sem a outra.

$\mathrm{Na}$ abordagem, tanto da biografia de Moraes Rego quanto da atuação da Comissão de Saneamento da Baixada, Fadel é minuciosa e oferece consistente documentação; recorre a fontes que vão desde familiares do biografado e obras de sua autoria até mensagens presidenciais e relatórios ministeriais. Além disso, utiliza ampla bibliografia sobre o tema. No que tange ao exame das fontes, saliente-se também o meticuloso trabalho da autora ao confrontar os relatórios da Comissão de Financiamento da Baixada com os do Ministério de Viação e Obras Públicas, os quais, muitas vezes, reproduziam as conclusões daquele. Fadel salienta, no entanto, as diferenças entre eles.

Nas relações do governo central com a classe dominante local, isto é, do Rio de Janeiro e sobretudo da Baixada Fluminense de então (em especial os setores fundiário e agrícola), era comum haver divergências na forma de ver os problemas da região. Esse foi o caso quando, em 1911, a Comissão de Saneamento da Baixada intimou "os proprietários das áreas saneadas pelo poder público a apresentar seus títulos de propriedade para avaliação e indenização dos imóveis", o que, todavia, não aconteceu, pois "a proposta de que o Governo Federal arcasse com esse custo e, posteriormente, o descontasse das indenizações pagas não foi aprovada pelo Congresso Nacional" (p.175). Por fim, a desapropriação de tais áreas nem sequer chegou a se concretizar. Na realidade, os relatórios do Ministério de Viação e Obras Públicas reproduziam os da Comissão de Saneamento da Baixada Fluminense omitindo, porém, detalhes pertinentes à necessidade de desapropriação de terras próximas a locais onde ocorriam beneficiamentos públicos, bem como outros tipos de sugestões.

Fadel observa como Moraes Rego, na condição de engenheiro-chefe da Comissão de Saneamento da Baixada, esteve atento à questão da ocupação dos terrenos beneficiados, considerando o seu futuro rendimento tanto quanto a conservação e manutenção das obras realizadas. Em relação a este último ponto, a autora nota que, diante da omissão por parte do governo central, a Comissão sugeriu que o estado do Rio de Janeiro ficasse com essa responsabilidade.

Fadel elabora um retrato da Baixada Fluminense do início do século XX baseando-se em relatos de naturalistas e viajantes que passaram pela região, e compara os períodos anterior e posterior à instalação da Comissão de Saneamento da Baixada. Observa o quanto a paisagem local e a organização espacial foram modificadas com a construção das estradas de ferro - e consequente substituição do transporte fluvial pelo ferroviário - e com o estabelecimento da produção agrícola próxima aos rios, além da desvalorização das localidades adjacentes. Destaque-se o fato de, à época, não se fazer menção a qualquer insalubridade da região, como se observa em anos posteriores, quando a estrada de ferro já se havia estabelecido na área. 
Segundo Fadel, as intervenções da Comissão de Saneamento da Baixada, no período entre 1910 e 1916, foram um marco para o entendimento do ambiente local. Para citar apenas o foco de atuação mais direta dessa Comissão, diferentes bacias hidrográficas foram unidas por meio de canais, e rios tortuosos foram retificados. Tais intervenções foram feitas conforme princípios modernizadores próprios dos engenheiros desse período, consolidados pelo saber técnico-científico dos politécnicos. No entanto, tais intervenções, conforme a análise da autora, não possuíam caráter meramente pontual; ao contrário, eram totalizantes e tinham como preocupação a ocupação dos terrenos e a ação do poder político, entre outros aspectos.

Devido ao tema e à abordagem, o trabalho de Fadel é relevante acadêmica e politicamente, sobretudo por articular a ação de um personagem na história e observar como as formas de vida - na feliz expressão de Gramsci (1999) - da região foram fruto tanto de uma construção histórica quanto da ação de homens determinados, e não de um acaso ou uma estrutura desencarnada.

O livro que vem a público torna-se, assim, importante não só para aqueles que se interessam pela história dos engenheiros, mas também para os que se interessam pela história do Rio de Janeiro e, mais particularmente, pela história da Baixada Fluminense: o modo pelo qual ela veio a ser o que é, excluída do processo de desenvolvimento econômico da região circundante e enfrentando graves problemas ecológicos que se estendem até os nossos dias.

Meio ambiente, saneamento e engenharia no Império e na Primeira República é leitura recomendada. Esperamos, ainda, que outros trabalhos venham caminhar pela mesma trilha e que a própria autora continue nos prestigiando com o tema e com novos trabalhos de relevância.

\section{REFERÊNCIAS}

BOURDIEU, Pierre.

A ilusão biográfica. In: Ferreira, Marieta;

Amado, Janaína (Org.). Usos e abusos da história oral. Rio de Janeiro: Fundação Getulio Vargas. 1996.
GRAMSCI, Antonio.

Cadernos do cárcere. Rio de Janeiro: Civilização Brasileira. v.1. 1999. 